\title{
TYPIFICATION OF CHRYSANTHEMUM ZAWADZKII (ASTERACEAE)
}

\author{
ZBIGNIEW SZELĄG \& YURIY KobIV
}

\begin{abstract}
The name Chrysanthemum zawadzkii Herbich is typified by the illustration published in the protologue, and epitypified by the specimen collected in 1832 by F. Herbich in the Pieniny Mts, Western Carpathians, and stored at the herbarium of the Ivan Franko National University of Lviv (LW). The original spelling of the species epithet is clarified.
\end{abstract}

Key words: Alexander Zawadzki, Asteraceae, Carpathians, Chrysanthemum, Dendranthema, epitype, Franz Herbich, lectotype, Tanacetum

Zbigniew Szelag, Institute of Botany, Jagiellonian University, Kopernika 31, 31-501 Kraków, Poland; e-mail: azszelag@wp.pl Yuriy Kobiv, Institute of Ecology of the Carpathians, National Academy of Sciences of Ukraine, Kozelnytska Str. 4, 79026 Lviv, Ukraine; e-mail: ykobiv@gmail.com

Only a few flowering plant taxa described from Poland have later been discovered over wider ranges in Europe or even shown to have a Eurasian distribution. A remarkable example is Chrysanthemum zawadzkii Herbich [= Dendranthema zawadzkii (Herbich) Tzvelev; = Tanacetum zawadzkii (Herbich) Pawł.] described from specimens collected in 1829 by Franz Herbich in the Pieniny Mts in the Western Carpathians (Herbich 1831: 6, 44). In addition to its isolated locality in the Pieniny Mts, Chrysanthemum zawadzkii occurs in a disjunct locality in the eastern part of European Russia, and over a large area of Asia, reaching Japan (Zarzycki 1976: distribution map).

Franz Herbich (1791-1865), a botanist and military medical doctor (for more details of Herbich's life see Knapp 1872), visited the Pieniny Mts in 1829, 1830 and 1832 (Herbich 1834: 572). Herbich bequeathed his herbarium to Edward Hückel (1830-1896), a botanist and school teacher who worked in several places in Eastern Galicia (now in Ukraine) (Köhler 2008). Later, Herbich's collection passed to the Lviv Botanical Garden and finally was housed in the herbarium of the Ivan Franko National University of Lviv (LW). A significant number of Herbich's specimens are also stored in the herbarium of the Natural History $\mathrm{Mu}-$ seum, National Academy of Sciences of Ukraine in Lviv (LWS), founded in 1859 as the Dzieduszycki
Family Museum, which was an important scientific center in the second half of the $19^{\text {th }}$ century. Many of Herbich's specimens, mostly related to the flora of Bukovina, are kept in the herbarium of the Yuriy Fedkovych National University of Chernivtsi (CHER).

In a search of Chrysanthemum zawadzkii original material, we checked all the mentioned herbaria as well as other important herbaria in Ukraine (KW) and Poland (KRA, KRAM, WRSL) from which some of Herbich's material was also known, and managed to find only two corresponding specimens in LW.

In 1939, Lviv (at that time it was part of Poland and called Lwów) was occupied by the Soviet Union and after World War II some of Herbich's specimens were taken to the herbarium of the V. L. Komarov Institute of Botany, Russian Academy of Sciences in Leningrad (now Sankt Petersburg in Russia) (LE), which was the main depository in the former Soviet Union.

In Flora of the USSR, Tzvelev (1961: 378) states that the 'type' of $C$. zawadzkii is stored in Vienna, whereas the 'isotype' is deposited in Leningrad. Thanks to help from the Curators of both main herbaria of Vienna, Dr. Walter Till (WU) and Dr. Bruno Wallnöfer (W), it was established that Tzvelev apparently meant the herbarium of the Museum of Natural History in Vienna (W), 
which in fact contains two specimens collected by F. Herbich in the Pieniny Mts. With the aid of Dr. Beata Paszko (KRAM) and Dr. Roman Ufimov (LE) we also managed to get access to the 'isotype' mentioned by Tzvelev as stored in LE. The efforts of Dr. Karel Sutorý (BRNM) and Professor Jan Kirschner (PRA) led to receipt of information on a specimen of C. zawadzkii stored at the Moravian Museum in Brno (BRNM).

Unfortunately, all of the six specimens we learned of were collected by F. Herbich in 1832 during his third trip to the Pieniny Mts on July 27, when on 'Berg Gacza bei Szczawnice' (now Mt. Kacza near Szczawnica) he gathered C. zawadzkii along with other plants (Herbich 1834: 574). As we did not find any specimens collected in 1829 , here we designate the original illustration from the protologue (Fig. 1) as the lectotype of the name C. zawadzkii and the specimen LW 214045 (Fig. 2) as its epitype.

\section{Chrysanthemum zawadzkii Herbich Figs 1-3}

Addit. ad Fl. Galic.: 44. 1831. - Tanacetum zawadzkii (Herbich) Pawł., Ochrona Przyrody 14: 64. 1934. - Dendranthema zawadzkii (Herbich) Tzvelev, Fl. USSR 26: 376. 1961. - TYPE LOCALITY: 'In cacuminibus montium Pienninorum et in rupibus calcareis prope Krościenko ad ripas fluvii Dunajec (bei der Uiberfahrt) ad Szczawnice'. - Lectotype (designated here): [icon in] F. Herbich, Addit. ad Fl. Galic.: Tab. 1831. - EPITyPE (designated here): In cacumine montis Gacza Pienninorum. Circuli Sandecien[sis] Galiciae legit August 1832 Auctor [F. Herbich] (LW 214045). - IsOEPITYPES: BRNM s.n., LE s.n., LW 214046, W 7789, W 49071.

ExsiCCATE SERIES: Fl. Polonica Exs., no. 182 (1894); Fl. Exs. Austro-Hung., no. 2673 (1896); Pl. Poloniae Exs., no. 272 (1936); Fl. Exs. Reipubl. Bohem. Slov., no. 1098 (1936); Fl. Poloniae Exs., no. 87 (1970).

Notes. A misspelling of the species epithet as 'zawadskii' first used by Tzvelev in Flora of the USSR (1961: 376) repeatedly occurs in the literature. Another erroneous version is 'zavadskii' (cf. Flora exsiccata Republicae Bohemicae Slovenicae, no. 1098). The species name Chrysanthemum zawadzkii was given in honor of Alexander Zawadzki (1798-1868), a botanist and professor at the University of Lviv in 1847-1852. The misspell- ing was adopted by such distinguished sources as Flora Europaea (Heywood 1976: 169), The Names of Plants (Gledhill 2006: 411), and The International Plant Names Index (http://www.ipni.org [accessed 30 November 2013]). Obviously the authors of these compendia were not familiar with the protologue of C. zawadzkii; therefore we present its original (Fig. 3).

Although Additamentum ad floram Galiciae (Herbich 1831) is a very rare publication, we happened to get access to a copy, in which pages 43 and 44 are transposed. In that copy the description of Chrysanthemum zawadzkii is placed on page 43 (no. 65) instead of page 44 (no. 67). Obviously it is a misprint, because the book's table of contents indicates page 44 for the description of this species. That copy is available at the library

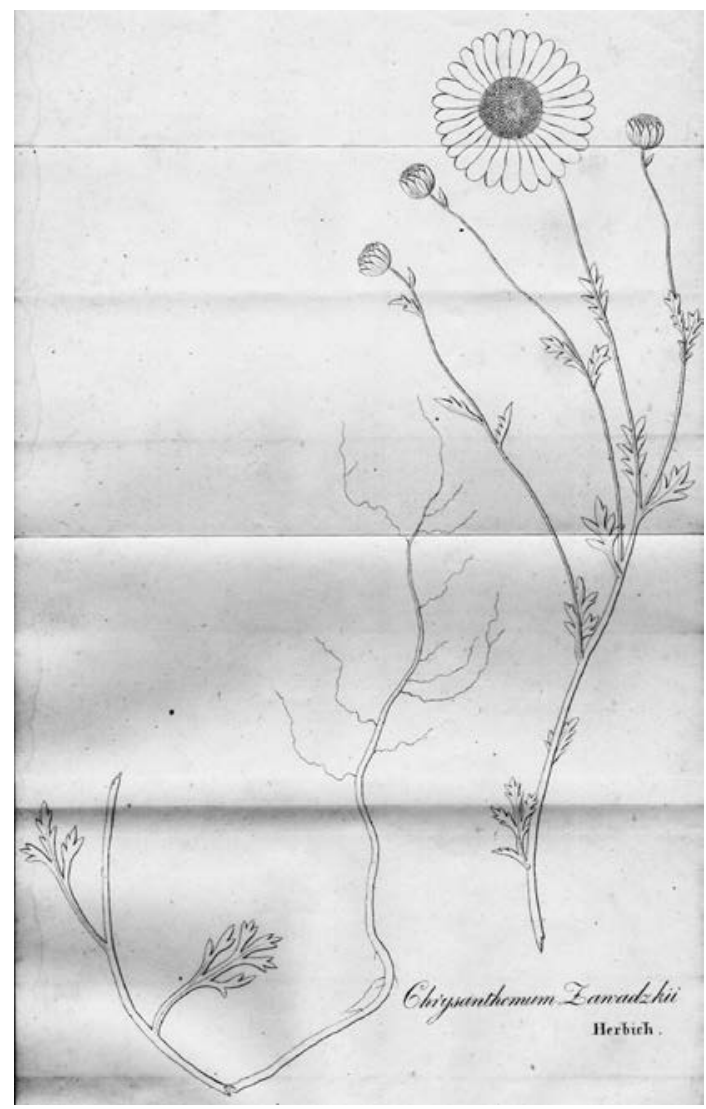

Fig. 1. Original illustration of Chrysanthemum zawadzkii Herbich (Herbich 1831: Tab.) selected as the lectotype. 


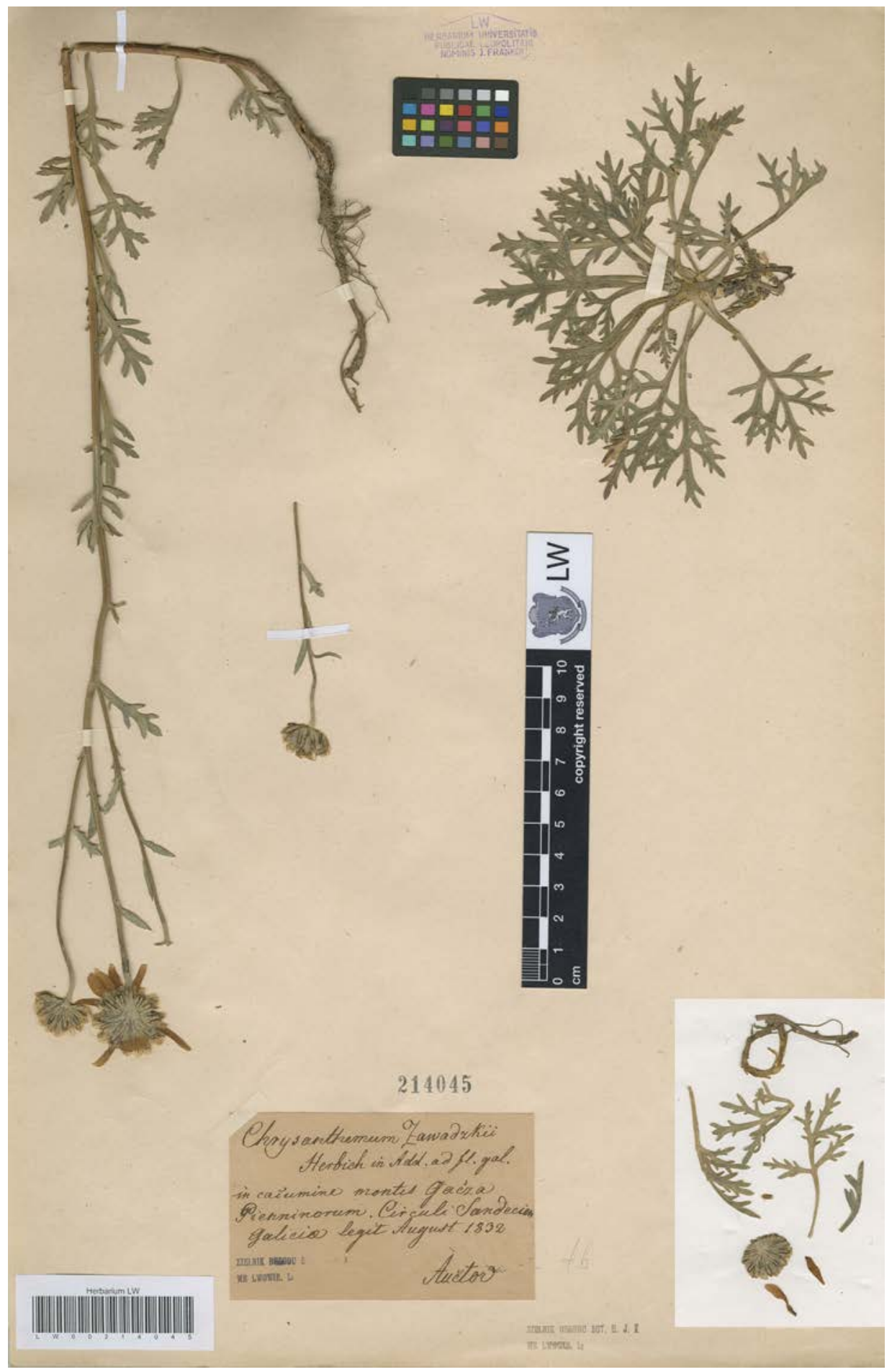

Fig. 2. Epitype of Chrysanthemum zawadzkii Herbich (LW 214045). 


\section{CHRYSANTHEMUM Zawadzkii: caule suffruticoso, corymboso, superne pubescente, foliis pinnatifi- dis, laciniis mucronatis. Nobis. Tabula nostra. \\ Radix perennis, longa, sublignosa. Caulis erec- tus, basi lignescens, purpureus, superne pubescens, corymbosus vel uniflorus. Folia glabra, carnosa, glau- cescentia; inferiora bipinnatifida; laciniis linearibus mucronatis, superiora pinnatifida, subfloralia, linea- ria, integra. Pedunculi pubescentes, uniflori. Caly- cis squarnae exteriores lanceolatae, margine membra- naceae, basi ciliatae, interiores lato-ovatae, mem- brana lata, scariosa, diaphana, cinctae. Flores spe- ciosi. Radius floris albus, subtus dilute roseus. Re- ceptaculum nudum, punctatum. \\ Hab. in cacuminibus montium Pienninorum et in rupibus calcareis prope Ḱrościenko ad ripas fluvii Du- najec (bei der Uiberfahrt) ad Szczawnice. \\ Floret Julio et Augusto.}

Fig. 3. Protologue of Chrysanthemum zawadzkii Herbich (Herbich 1831: 44).

of Vienna University. Most likely some other remaining copies contain the same error.

ACKNOWLEDGements. We are grateful to the Curators of the cited herbaria for making the relevant collections available for study, to Tetiana Khmil (LW), Beata Paszko (KRAM), Armin Löckher (W) and Karel Sutorý (BRNM) for photographing Herbich's specimens, and to Piotr Köhler (Kraków) for information on Herbich's activity. We thank Jan Kirschner (Průhonice) and an anonymous reviewer for critical remarks on the manuscript.

\section{REFERENCES}

GLEDHILL D. 2006. The Names of Plants. Cambridge University Press, Cambridge.

Herbich F. 1831. Additamentum ad floram Galiciae. Kuhn et Millikowski, Leopoli, Stanislavoviae et Tarnoviae et C. Wenzel, Przemysliae.
Herbich F. 1834. Botanischer Ausflug in die galizisch-karpatischen Alpen des Sandezer Kreises. Flora 17: 561-575.

Heywood V. H. 1976. Dendranthema. In: T. G. Tutin, V. H. Heywood, N. A. Burges, D. M. Moore, D. H. Valentine, S. M. Walters \& D. A. WebB (eds), Flora Europaea 4: 169. Cambridge University Press, Cambridge.

KnapP J. A. 1872. Die bisher bekannten Pflanzen Galiziens und der Bukowina. Wilhelm Braumüller, Wien.

KöHLER P. 2008. Dictionary of Polish botanists. 66. Edward Antoni Hückel. Wiadom. Bot. 52(1/2): 63-66 (in Polish).

Tzvelev N. N. 1961. Rod 1541. Dendrantema-Dendranthema (DC.) Des Moul. emend. Tzvel. In: B. K. Shishkin \& E. G. Bobrov (eds), Flora URSS 26: 364-388. Editio Academiae Scientiarum URSS, Mocqua - Leningrad (in Russian).

ZARZYCKI K. 1976. Small populations of relict and endemic plant species of the Pieniny Mts. (Western Carpathians), their endangerment and conservation. Ochr. Przyr. 41: 7-75 (in Polish with English summary). 